\title{
Success factors in university-industry PhD projects
}

\author{
Negin Salimi ${ }^{1, *}$, Rudi Bekkers ${ }^{2}$ and Koen Frenken ${ }^{3}$
}

${ }^{1}$ School of Innovation Sciences, Eindhoven University of Technology, The Netherlands. Current address: Faculty of Technology, Policy and Management, Delft University of Technology, Jaffalaan 5, 2628 BX, Delft, The Netherlands, ${ }^{2}$ School of Innovation Sciences, Eindhoven University of Technology, Postbus 513, 5600 MB, Eindhoven, The Netherlands, and Dialogic innovatie \& interactie, Utrecht, The Netherlands, ${ }^{3}$ School of Innovation Sciences, Eindhoven University of Technology, The Netherlands. Current address: Innovation Studies, Copernicus Institute of Sustainable Development, Utrecht University, Heidelberglaan 2, 3584 CS, Utrecht, The Netherlands

*Corresponding author: Email: n.salimi@tudelft.nl

\begin{abstract}
Faced with ever-increasing pressure to innovate, firms consider universities to be significant sources of knowledge. Such knowledge flow can take place in a variety of ways such as academic publications and contract research, but also in more collaborative modes such as joint research projects. This paper focuses on a specific collaborative model, in which firms and universities are involved together in a PhD project. We analyze the effects of project management, communication, and supervision characteristics on the success of such PhD projects using a survey conducted at Eindhoven University of Technology, the Netherlands. We conclude that management decisions, supervision and communication characteristics have a significant impact on the ultimate success of a project. Among other things, the choice of university supervisor plays a pivotal role. Success is more likely if there is joint decision-making by both university and partner. We believe our findings help universities and firms to collaborate successfully.

Key words: university-industry collaborations; collaborative PhD projects; collaboration success.
\end{abstract}

\section{Introduction}

In the past decade, there has been considerable evidence of an increase in linkages between universities and industry, including the growing propensity of universities to patent (Nelson 2001), universities' growing licensing revenues (Thursby et al. 2001), an increasing number of university spin-offs (Shane, 2005), and an increasing number of science parks (Siegel et al. 2003b). There is already a considerable empirical literature on the transfer of knowledge from university to industry (Tijssen 2012; Ryan et al. 2008; Baldini 2006; Dutrénit et al. 2010; Fernandes et al. 2010). Most studies focus on formal, non-collaborative forms-such as patenting and licensingwhile some recent studies also highlight the importance of collaborative forms (Bekkers and Bodas Freitas 2008; Perkmann et al. 2013). Going beyond mere commercialization of academic knowledge, Perkmann et al. (2013) introduce the concept of academic engagement, defined as:

... knowledge related collaboration by academic researchers with non-academic organizations.

This definition includes differentiated forms of interaction, from formal activities such as collaborative research, contract research and consulting, to informal activities such as attending meetings or conferences (D'Este and Patel 2007; Grimpe and Hussinger 2013).

A key form of university-industry collaboration, which has nevertheless received relatively little scholarly attention, is joint $\mathrm{PhD}$ projects. Here, we define a collaborative $\mathrm{PhD}$ project as:

... a project with a typical duration of 3-4 years and which involves a university, a firm, and a $\mathrm{PhD}$ candidate, all working together to meet (common or individual) expectations.

Doctoral candidates are not only key producers of new knowledge but potentially also important channels for transferring such knowledge to firms (Thune 2009). In this context, studies have hitherto focused on comparing joint $\mathrm{PhD}$ projects with university $\mathrm{PhD}$ projects in terms of their outputs. For example, Lin and Bozeman (2006) found the negative impact of industry involvement on the scientific productivity of $\mathrm{PhD}$ candidates during their entire career, while Salimi et al. (2015b) found that the output and impact of the $\mathrm{PhD}$ project itself was higher for collaborative projects compared to in-house university projects. There is further evidence that industry involvement in $\mathrm{PhD}$ projects leads to higher patenting rates (Gemme and Gringas 2004) and job opportunities (Mangematin 2000; Mougérou 2001), although one study did not find such an effect (Enders 2002). 
The question of what factors drive the success or failure of collaborative $\mathrm{PhD}$ projects, however, has remained largely unanswered (Butcher and Jeffrey 2007; Thune 2009). We know that for university-industry collaboration in general, despite the perceived mutual benefits, success is by no means guaranteed. There are high failure rates in R\&D collaboration (Brouthers et al. 1997) and many projects report considerably lower outcomes than expected (Spekman et al. 1998). Various factors can cause collaborations to fail such as: choosing an inappropriate partner for collaboration (Beamish and Inkpen 1995), coping with management issues (Dodgson 1991; Kelly et al. 2002) and communication problems (Kelly et al. 2002). In addition, supervision characteristics are also expected to affect the success of projects (Butcher and Jeffrey 2007).

Based on an extensive survey among past $\mathrm{PhD}$ students engaged in university-industry projects, this study analyses how the management, supervision and communication characteristics of projects impact on their success. This paper contributes to the literature in three ways. First, it fills a gap in the area of determinants of success in university-industry collaboration. Second, it is one of the very few contributions that focuses on collaborative $\mathrm{PhD}$ projects (Butcher and Jeffrey 2007; Thune 2009). Such collaborations are quite common, especially at technical universities. At the university where we collected our data, almost one-third of all 1,783 doctoral theses published in the period 2000-2011 were the result of a collaboration. Third, we measured the success of collaboration as a construct with multiple components, whereas previous studies tend to focus only on one aspect of success (Butcher and Jeffrey 2007). We also believe that this study, in addition to its scientific contributions, has several practical implications, not only for universities, but also for their partners in industry, that could increase the chance of collaboration success. More precisely, an understanding of the success factors underlying joint $\mathrm{PhD}$ projects between universities and industries can increase the benefits and reduce the risk in these inherently costly and complex projects.

The remainder of this paper is organized as follows. In Section 2, we review the literature on collaboration dimensions and their characteristics, as well as the literature on measuring collaboration success. In Section 3 we propose a methodology to investigate the relationship between management, supervision and communication characteristics on the one hand and project success on the other. Then, in Section 4, we present our empirical analysis and discuss the findings. The paper ends with conclusions, managerial implications and possible directions for future research.

\section{Success factors in collaborative PhD projects}

The literature on inter-organizational collaboration highlights several factors that can influence collaboration success. Three main dimensions, identified by Amabile et al. (2001), are:

- characteristics of the collaborative team

- characteristics of the collaboration environment

- collaboration processes

They found three factors in particular that are important for successful collaborations:

- skills and knowledge of project leader

- mutual trust

- a high frequency of communication
Literature on other forms of collaboration with firms looked at factors leading to failed collaborations, such as the selection of an inappropriate partner for collaboration (Beamish and Inkpen 1995), and communication problems and management issues (Kelly et al. 2002). How the partners in a collaboration manage their activities is another factor that influences the success of the venture (Starbuck 2001; Morandi 2013). In fact, this dimension of collaboration emphasizes the joint action and behavior among collaborative partners. Based on this view, partners who become involved in collaboration must learn how to manage their relationships in order to make joint decisions, as well as finding a way to solve problems and conflicts (Artz and Brush 2000). Here, the significant management characteristics of a collaboration include: who had the initial idea for the collaboration (Bekkers and Bodas Freitas 2011), who is most prominent in managing the relationship (Butcher and Jeffrey 2007), and how risks or rewards are shared (Ostrom 1990; Lambert 2008).

Thomson and Perry (2006) argue that managing the cooperation is at the 'heart of collaboration', focusing on the negotiation between, and commitment of, partners. In order to achieve joint management and decision-making among partners, trust (Ostrom 1990; Lambert 2008) and commitment (Mattessich and Monsey 1992; Barnes et al. 2002; Lambert 2008) can be seen as necessary conditions. These aspects of collaboration can be created by maintaining close relationships and good communication between partners (Mattessich and Monsey 1992; Lambert 2008). Therefore another crucial dimension of collaboration is how the partners in a project communicate with each other (Senker et al. 1998; Rappert et al. 1999; Schartinger et al. 2002).

In the specific case of a collaborative $\mathrm{PhD}$ project, supervisors in both university and industry are vital partners who play an important role in order to achieve a higher outcome (Thune 2009). SalminenKarlsson and Wallgren (2008) focused on the role of university supervisors and firm supervisors of graduate candidates in the specific context of industrial research schools, within the special framework of Swedish higher education. They found that collaboration between university supervisors and industry supervisors requires ongoing cooperation between them, even in other areas (i.e. personal relations), as well as frequent meetings. Moreover, the mutual understanding, similar motivations and goals of supervisors are other elements of successful collaboration (Butcher and Jeffrey 2007). Hence, supervision is another dimension of university-industry collaboration that can be considered to be a factor in success.

In sum, there are many factors influencing the research process in a joint $\mathrm{PhD}$ project between universities and industries. These factors can be grouped under the headings of management, supervision and communication characteristics. These are also the dimensions proposed in the framework by Butcher and Jeffrey (2007). By conducting interviews among research funders and managers, they identified these three dimensions as the main success determinants in collaborative $\mathrm{PhD}$ projects. In what follows, we will use the framework proposed by Butcher and Jeffrey. The question that now follows is how to measure the success of collaborative $\mathrm{PhD}$ projects.

We should stress that in this study, success refers to the extent to which the collaboration's goals are met. Here, the view of collaboration is based on 'civic republicanism'. Thus, despite existing differences, actors collaborate to achieve mutual understanding, trust, and implementation of shared preferences (March and Olsen 1989). We do, however, acknowledge that each partner may have their own interpretation of the collaborative achievement. This interpretation is called satisfaction and can be distinguished from the success 
seen in the work by Behrens and Gray (2001) in which they state that a collaborative project is successful if all the partners are satisfied with the collaboration. The basis of their perspective is 'classic liberalism', whereby each actor engages in the collaboration to achieve their own goals and interests without considering other actors' preferences (Thomson and Perry 2006).

There is currently no agreement in the literature about how to assess the success of collaborative $\mathrm{PhD}$ projects. For instance, Butcher and Jeffrey (2007) investigated the correlation between collaboration success factors such as supervisor, project management and communication and the perceived collaborative research success (from the PhD candidate's perspective). In doing this, Butcher and Jeffrey did not consider different components when measuring collaboration success. Other studies have also measured success from a single component alone, such as: knowledge transferring ability between partners, the development and commercialization of a new product (Bekkers and Bodas Freitas 2011). Siegel et al. (2003a) identify how technology as one output of university-industry collaboration, is successfully transferred and the strategies for improving technology transfer.

Other researchers mention different components for the success of university-industry collaboration without considering these different components in their analyses. For instance, Santoro (2000) mentions that tangible technological outcomes (e.g. publication, patent, patent application) along with knowledge sharing are components of success in university-industry collaborations. Barnes et al. (2002) identified success as a construct with multiple components. They evaluated six collaborative research projects between university and industry and identify different components for collaboration success. They evaluated the projects' outcomes based on two types of components: subjective and objective. For their subjective evaluation, they relied on the main participant's perception about the extent to which their expectations were met. In terms of objective success components, they considered the number of publications, patents, new product, new process and technology development. However, their work is a conceptual study based on six case studies.

As success is a multi-dimensional concept, we chose to investigate the effects of success determinants on different components of success. While focusing specifically on collaborative $\mathrm{PhD}$ projects and studying the existing literature, we aim to consider all the relevant components of success. Our starting point is to recognize the complex nature of joint $\mathrm{PhD}$ projects in that not two, but three partners need to be distinguished: the PhD student, the university supervisor and the supervisor at the partner organization. Moreover, the type of collaboration is specific in its long duration (typically four years or longer) compared to contract research which generally has a much shorter duration. The type of knowledge central to these collaborations-new scientific knowledge-makes collaborative $\mathrm{PhD}$ projects different from other types of collaboration (Salimi et al. 2015a). By reviewing the literature on the $\mathrm{PhD}$ candidates, Thune (2009) found that scholarly productivity (i.e. publications and presentations), commercial productivity (i.e. patent and trade secrets), and the future career of $\mathrm{PhD}$ candidates are variables that are considered as outcomes of collaborative $\mathrm{PhD}$ projects. In line with Thune's study, we measure a project's success using multiple components. We look at formal outputs including publications and patents as well as whether the relationship between the university and its partner has been continued and whether the $\mathrm{PhD}$ candidate was offered a job. In addition to these variables resembling Thune's study, we also specifically look at knowledge transfer using a progressive scale (see Section 3) as to be able to assess how valuable the knowledge transfer has been for the receiving partner.

\section{Data and methodology}

\subsection{Data collection}

We conducted a survey in order to examine how university and industry build their relationships through collaborative $\mathrm{PhD}$ projects and how different collaboration dimensions impact on different collaboration success measurements. In our study, the collaborative $\mathrm{PhD}$ project is the unit of analysis. Our population is defined as $\mathrm{PhD}$ projects involving Eindhoven University of Technology (TU/e) and a firm or public research organization (PRO) that resulted in a published $\mathrm{PhD}$ thesis in the period $2000-11 .^{1}$ It is important to stress that in the Netherlands, most of the PROs rely heavily on contract research and other sources of commercial funding, and have very limited public funding, quite differently from PROs in many other countries that are much closer to government agencies. ${ }^{2}$ There is a specific reason why we decided to collect data for our study at a technical university. As argued by Stephan et al. (2004), doctoral education in science and engineering is critical to the role universities play in fostering economic development. Therefore we are much more likely to find this type of collaboration (industry-university) in technical rather than other universities.

Looking at all 1,783 doctoral theses published in the period 2000-11 at the TU/e, we determined that 496 (28\%) of all PhD theses resulted from a collaboration with a firm or PRO (in this paper we call these a 'collaborating partner' or simply a 'partner'). ${ }^{3}$ For 408 of these, we were able to retrieve up-to-date contact details of the former $\mathrm{PhD}$ candidate. We then approached the full population of 408 former PhD candidates. Data acquisition took place between January and April 2012. After sending two reminders, we received a total of 191 complete and valid responses, of which 103 represented collaboration with firms and 88 with PROs, bringing our overall response rate to $47 \%$.

Collaboration success can be measured by collecting data from one of the collaboration partners (industry, university, $\mathrm{PhD}$ candidate) and in an ideal situation, from all partners. Partners may differ in their evaluation of the success of the collaboration, depending on their perspective (Bekkers and Bodas Freitas 2011). In this study, although the data has been collected through PhD candidates, we considered all the partners' perspectives. Barnes et al. (2002) show that a $\mathrm{PhD}$ candidate's opinion and experiences as a main actor in the collaborative project give us access to both the industry and academia perspectives. In addition to the $\mathrm{PhD}$ candidate's pivotal role in the collaboration, the easier accessibility of $\mathrm{PhD}$ candidates is also relevant from a practical viewpoint. ${ }^{4}$ If we were to require all the partners' opinions on a specific project, the response rate would decrease dramatically, thus hampering the data analysis. ${ }^{5}$ Therefore in terms of subjective evaluation for this study, the measurement of collaboration success depends on the $\mathrm{PhD}$ candidate's perception and experience.

However, measuring from a single source may cause concern in terms of common method variance. To reduce such bias as much as possible, we implemented measures as suggested by Podsakoff et al. (2003). Among other things, we designed the survey questionnaire with differently formatted responses (e.g. Likert scale, ordinal, categorical, and dichotomous). Having tried out the draft questionnaire in a pilot test, and based on the respondents' feedback, we improved the text. In particular, we addressed any perceived ambiguity, 
removed some concepts that were found to be vague, defined unfamiliar terms, and added examples. Apart from all these solutions, and to ensure there would be no common method bias, after conducting our survey, we used Harman's one-factor test. This technique involves all the (independent and dependent) variables being entered into an exploratory factor analysis (Podsakoff et al. 2003). Based on the result of the factor analysis, 13 factors were extracted, accounting for $71.8 \%$ of the total variance (the first factor accounts for $11.5 \%$ of the total variance). This suggests that our study does not suffer from common method bias.

Finally, to check for non-response bias, we used the projected respondent method offered by Armstrong and Overton (1977). This method assumes that non-respondents are more similar to late respondents. We compared non-respondents with two waves of respondents and found no indications of non-response bias.

\subsection{Variables}

Table 1 provides an overview of the dependent variables for this study. Wherever possible when evaluating collaboration, we used factual, objective measurements by considering all relevant success measurements. The first—and perhaps the most important-measurement was of the level of knowledge actually transferred to and used by the partner (Bekkers and Bodas Freitas 2011). The extent to which the knowledge $\mathrm{PhD}$ candidates developed in their theses has been adopted by industry is measured in a progressive scale. In the preliminary stages, this knowledge may not be transferred at all. The next stage, knowledge transfer, makes that knowledge effectively available to industry staff working in this field and for instance accessible in libraries or being presented to staff. Once industry researchers have studied and mastered the transferred knowledge, absorption has taken place. The next stage occurs when the absorbed knowledge is applied in a business context. The final step is commercialization, which can be a small part, or form the basis, of a product or process. This measurement uses a progressive, ordinal scale as specified in Table 1, for which we applied the ordinal logit model in analysis.

Our other success variables are dichotomous variables. Whether a project resulted in academic publication or whether knowledge was patented (Barnes et al. 2002) are dichotomous variables. Furthermore, we measured whether the relationship between university and partner was continued (van Gils 2012). Because the $\mathrm{PhD}$ candidates can form and maintain the relation between university and its partner, after finalizing the $\mathrm{PhD}$ project, the university and the partner can become engaged in a new collaboration (Thune 2009). Other consequences of collaborative PhD projects can be whether the university or partner offered the $\mathrm{PhD}$ candidate a job after graduation. As such, we considered a job offer to a PhD candidate from a university or its partner to be a proxy of a successful collaboration. We used a binary logit model to analyze these dichotomous variables. Details of our dependent variables, including the phrasing of the underlying question in our survey, are given in Table A. 1 in the Appendix.

Table 2 reports the correlation between dependent variables. For the correlation between the first dependent variable (level of knowledge transfer) and other dependent variables, we used the MannWhitney test and the Phi coefficient for the remaining variables. As can be seen from Table 2, almost all the correlations are very low, suggesting a high discriminate validity (Hair et al. 2006).

Table 3 is an overview of the independent variables. As discussed in Section 2.2, we asked respondents to evaluate their $\mathrm{PhD}$ projects in terms of 'project management', 'characteristics of supervisor' and 'communication'. Based on the first dimension of collaboration, we identified project management characteristics such as which partner(s) is responsible for funding the project, managing the coordination, making decisions on the content of project, and if any publication is prohibited due to industry restrictions.

Because of the important role that supervisors play in collaborative $\mathrm{PhD}$ projects, we considered supervision characteristics as a second dimension of collaboration. This aspect is measured by various characteristics such as both the university supervisor and its partner supervisor's level of knowledge about the PhD topic, the enthusiasm of both supervisors for being involved in the project, their level of openness to any new ideas and similar opinions between both supervisors on the PhD topic. Further factors are: the effect of the university supervisor's academic position, the industry supervisor's academic degree and the replacement of any of the supervisors during the $\mathrm{PhD}$ project.

With respect to the third dimension of collaboration, we considered the communication characteristics between partners in a collaborative $\mathrm{PhD}$ project. We measured this aspect by considering the

Table 1. Descriptive statistics of dependent variables

\begin{tabular}{|c|c|c|}
\hline Dependent variable & Values & $\mathrm{N}$ \\
\hline Level of knowledge transfer to partner & $\begin{array}{l}\text { Not transferred at all: } \mathrm{n}=20(11 \%) \\
\text { Transferred }^{(\mathrm{a})}: \mathrm{n}=78(41 \%) \\
\text { Absorption }^{(\mathrm{b})}: \mathrm{n}=46(24 \%) \\
\text { Application }^{(\mathrm{c})}: \mathrm{n}=25(13 \%) \\
\text { Commercialization as a smaller element of product or process: } \mathrm{n}=12(6 \%) \\
\text { Commercialization as the main basis of product or process: } \mathrm{n}=8(4 \%)\end{array}$ & 189 \\
\hline Resulted in academic publication $^{(\mathrm{d})}$ & Yes: $\mathrm{n}=168(89 \%)$ & 189 \\
\hline Knowledge was patented $^{(\mathrm{e})}$ & Yes: $\mathrm{n}=48(25 \%)$ & 189 \\
\hline Subsequent job offer from university & Yes: $\mathrm{n}=41(22 \%)$ & 189 \\
\hline Subsequent job offer from partner & Yes: $\mathrm{n}=60(32 \%)$ & 189 \\
\hline Collaboration was followed up & Yes: $\mathrm{n}=129(81 \%)$ & 160 \\
\hline
\end{tabular}

(a) Knowledge is now effectively available to the staff of the collaborating partner working in this field. It is for instance available in the library, or there has been a presentation

(b) Collaborating partner's researchers have studied and now master this knowledge

(c) Knowledge is being used by the collaborating partner in a business context

(d) $\mathrm{PhD}$ project resulted directly in publications in academic journals (either during or after finalization)

(e) $\mathrm{PhD}$ project resulted in one or more patents or patent applications, with the $\mathrm{PhD}$ candidate listed as inventor 
quality and frequency of meetings between $\mathrm{PhD}$ candidates and their supervisors both at the university and at the partner, as well as between the supervisors in both locations.

All continuous variables were measured on a five-point Likerttype scale. Details on our independent variables, including the phrasing of the underlying questions in our survey, can be found in Table A.2 in the Appendix.

We further considered the effect of five control variables for an alternative explanation of the phenomena measured. These control variables are:

1. Whether the partner's office is in the same city as the university.

2. Whether the collaboration is with a PRO (as opposed to a firm).
3. Whether the PhD candidate is a former employee of the partner.

4. Whether there was a prior relationship between the TU/e and the partner.

5. Whether there are differences across disciplines.

All the first four variables reflect a form of proximity between partners (Boschma 2005; Ponds et al. 2007; Balland 2012), including: geographical proximity (1), institutional proximity (2) and social proximity ( 3 and 4$)$. In all cases, one can expect that proximity is supportive of trust, which benefits the complex coordination process. Hence, one expects positive signs for all four control variables. Finally, we use dummies for each university department to control for structural differences across disciplines. Details on our

Table 2. Correlation between dependent variables

\begin{tabular}{|c|c|c|c|c|c|}
\hline Variables & $\begin{array}{l}\text { Level of } \\
\text { Knowledge } \\
\text { transfer }^{1}\end{array}$ & $\begin{array}{l}\text { Resulted in } \\
\text { academic } \\
\text { publication }^{2}\end{array}$ & $\begin{array}{l}\text { Knowledge } \\
\text { was patented }^{2}\end{array}$ & $\begin{array}{l}\text { Subsequent job offer } \\
\text { from university }\end{array}$ & $\begin{array}{l}\text { Subsequent job } \\
\text { offer from partner }\end{array}$ \\
\hline Resulted in academic publication & 1795.5 & & & & \\
\hline Knowledge was patented & $2842 *$ & -0.080 & & & \\
\hline Subsequent job offer from university & 2825 & 0.039 & -0.101 & & \\
\hline Subsequent job offer from partner & $2575.5^{* * *}$ & 0.010 & 0.098 & -0.056 & \\
\hline Collaboration was followed up & 1966.500 & -0.024 & -0.002 & 0.081 & -0.018 \\
\hline
\end{tabular}

$* \mathrm{p}<0.10, * \mathrm{p}<0.05, * * \mathrm{p}<0.01$

1. Mann-Whitney test was used to measure the association between this ordinal variable and other dependent variables

2. Phi coefficient was used to measure the association between dichotomous variables

Table 3. Descriptive statistics of independent variables

\begin{tabular}{llll}
\hline Independent variable & Values/mean & S.D & Min Max N
\end{tabular}

Project management aspects:

$\mathrm{PhD}$ project funder

Prominent partner in managing coordination

Type of decision-making between both partners

Publication was prohibited due to partner's restrictions Characteristics of supervisor:

Academic position of university daily supervisor

Academic degree of partner daily supervisor

Level of university supervisor's knowledge in $\mathrm{PhD}$ topic Level of partner supervisor's knowledge in $\mathrm{PhD}$ topic Level of university supervisor's enthusiasm in PhD topic Level of partner supervisor's enthusiasm in $\mathrm{PhD}$ topic Similar opinion between university and partner supervisors on $\mathrm{PhD}$ topic Replacing any of the supervisors during the $\mathrm{PhD}$ project

Openness of university supervisor to any idea

Openness of partner supervisor to any idea

Characteristics of communication:

Meeting frequency of $\mathrm{PhD}$ candidate and university supervisor

Meeting frequency of $\mathrm{PhD}$ candidate and partner supervisor

Meeting frequency of both supervisors

Quality of communication between $\mathrm{PhD}$ candidate and university supervisor Quality of communication between $\mathrm{PhD}$ candidate and partner supervisor
Collaborating partner: $\mathrm{n}=109(57 \%)$

Others: $\mathrm{n}=82(43 \%)$

University: $\mathrm{n}=88(46 \%)$

Collaborating partner: $\mathrm{n}=38(20 \%)$

Both partners: $\mathrm{n}=65(34 \%)$

By the university: $\mathrm{n}=93(49 \%)$

By the collaborating partner: $\mathrm{n}=37(19 \%)$

Both partners: $\mathrm{n}=61(32 \%)$

Yes: $\mathrm{n}=19(10 \%)$

Assistant professor: $\mathrm{n}=92(48 \%)$

Associate professor: $\mathrm{n}=51(27 \%)$

Full professor: $\mathrm{n}=48(25 \%)$

Bachelor or Master: $\mathrm{n}=23(12 \%)$

PhD: $\mathrm{n}=88(46 \%)$

Assistant/associate/full professor: $\mathrm{n}=80(42 \%)$

4.0785

3.9144

4.2094

3.8871

3.5225

Yes: $\mathrm{n}=32(17 \%)$

No: $n=159(83 \%)$

4.0160

3.7104

4.8848

3.8953

3.2670

4.0209

3.6754

$\begin{array}{llll}0.894 & 1 & 5 & 191 \\ 1.156 & 1 & 5 & 187 \\ 0.869 & 1 & 5 & 191 \\ 1.130 & 1 & 5 & 186 \\ 1.218 & 1 & 5 & 178\end{array}$
191

$\begin{array}{llll}0.904 & 1 & 5 & 188\end{array}$

$\begin{array}{llll}1.031 & 1 & 5 & 183\end{array}$

$\begin{array}{llll}1.475 & 1 & 7 & 191\end{array}$

$\begin{array}{llll}1.903 & 1 & 7 & 191\end{array}$

$\begin{array}{llll}1.383 & 1 & 5 & 191\end{array}$

$\begin{array}{llll}0.978 & 1 & 7 & 191\end{array}$

$\begin{array}{llll}1.218 & 1 & 7 & 191\end{array}$ 
control variables, including the phrasing of the underlying questions in our survey, can be found in Table A.3 in the Appendix. Table A.4 (also in the Appendix), which provides the correlation between all the independent and control variables, shows that these correlations are quite low. We assessed the potential multicollinearity between independent variables in each of the three regression models. In the first model below (the effect of project management on success), the variance inflation factor (VIF) is in the range 1.035-2.009. That is, the tolerance $(1 / \mathrm{VIF})$ is greater than 0.4 , well above the critical value of 0.2 (Menard 1995). With respect to our second model (the effect of supervisors on success), VIF is in the range 1.091-1.884 (equivalent to tolerances greater than 0.5 ). For the last model (the effect of communication on success), VIF is in the range 1.186-1.466, which means that the tolerance is greater than 0.6. These results suggest that our study does not suffer from multicollinearity. Furthermore we investigated the multicollinearity between all independent variables (see Section 4.4).

\section{Results and discussion}

As discussed above, we distinguished three collaboration dimensions: project management, supervision, and communication. Our main results for these groups are shown in Tables 4-6 (and discussed Sections 4.1-4.3, respectively). In each table we have two columns for every dependent variable, one without the control variables (see Section 3), and one with these variables. Our discussion of the results will be based solely on the regressions including the control variables, as these are the most reliable.

\subsection{How does project management affect collaboration success?}

We will discuss the findings of our analysis, starting with how project management is related to our various measurements of collaborative success (see Table 4).

The first dependent variable is the level of knowledge transfer (Table 4, columns 1 and 2). As discussed earlier, this is an ordinal variable, for which we use the ordinal logit model. We found that knowledge transfer is supported by joint decision-making, suggesting that joint involvement in the content part of a project is indeed helpful for knowledge transfer through the $\mathrm{PhD}$ candidate. This result is in line with what is found in the literature that emphasizes the role of collaborative $\mathrm{PhD}$ candidates in transferring knowledge from the university to the industry (Mangematin 2000; Mougérou 2001). Knowledge transfer is also supported by a publication restriction imposed by the partner. Arguably, this is because such cases represent strategic knowledge that the partner is keen to obtain (and keen to patent). In terms of our control variables, we find that a former employee of the partner is more effective in transferring knowledge than other $\mathrm{PhD}$ candidates, probably because of the familiarity of the candidate with the organizational context in which $s($ he) he operates.

For our second outcome variable, academic publications (Table 4, columns 3 and 4), we found no significant relationships. Apparently, project management aspects do not affect the likelihood of $\mathrm{PhD}$ candidates having their results published in academic journals.

Our third outcome variable considers whether the developed knowledge is patented (Table 4, columns 5 and 6). We found that the likelihood of patents is: first, positively related to the partner funding the project. Arguably, this might be because the partner sees more commercial potential in the project, or has more control of the scientific direction. This finding is in agreement with Czarnitzki and Fier (2003), who found that if a project is funded by a firm, the likelihood of patents increases because of the focus on commercialization activities. Second, the likelihood of patents is negatively related to joint management. Third, the likelihood of patents is positively related to a publication restriction imposed by the collaborating partner. This result is expected since a publication restriction is usually aimed at ensuring outcomes meet the novelty requirement of the patent office. Interestingly, the restriction does not negatively affect the likelihood of publication. In the control variables, we see that patenting likelihood increases if the partner's office is situated in the same city as the university. When considering this result, however, we should bear in mind that our data was collected at the TU/e located in a city that is also home to Philips research and many other Philips offices that collaborate with this university. With over 54,000 patents, Philips is a highly patent-intensive company and this may affect our results. We also observed that the positive effect of funding by a partner and publication restriction still remain significant after adding control variables that show the robustness effect of these two independent variables. Furthermore, collaboration with a PRO as opposed to a firm is less likely to result in patents than one with a firm, which is not surprising.

Our fourth and fifth outcome variables are whether the $\mathrm{PhD}$ candidate-after successful completion of the project-is offered a job by the university or the collaboration partner respectively (Table 4, columns 7-10). Interestingly, a job offer by a university is less likely if the partner was involved in managing the relationship, either alone or together with the university. Although we have no exact idea why this would be the case, we only know that it is not due to the candidate having already been employed by the partner, because we included that as a control variable and it remains insignificant. A job offer by the partner is not related to any project management aspects, yet, unexpectedly, it is negatively affected by a prior relationship between the university and the partner.

Our sixth and final outcome variable is whether the collaboration was followed up by a new one (Table 4, columns 11 and 12). Here we observed that such a follow-up is more likely if the partner funded the project. This result still remains significant after adding control variables showing the robustness effect of this independent variable. We also observed that this is more likely if the project was also preceded by other collaboration. Thus, we observe evidence of long 'chains' of subsequent collaborations indicative of long-term partnerships.

\subsection{How do supervisors affect collaboration success?}

Table 5 shows our regression results of the effect of supervisors' characteristics on the six different success measurements.

Table 5, columns 1 and 2 show that the level of knowledge trans$\mathrm{fer}$ is, first, negatively related to the level of university supervisor knowledge. Indeed, a supervisor with a high knowledge level may well be more interested in publications than in facilitating knowledge transfer. Second, is positively related to both supervisors having similar opinions as can be expected. Third, it is negatively related to supervisor replacement during the project, again, as can be expected. Knowledge transfer is also more likely if the $\mathrm{PhD}$ candidate is a former employee of a partner. Again, this effect most probably reflects the candidate's familiarity with the organizational context.

With regard to having an academic publication as outcome of a collaborative PhD project (Table 5, columns 3 and 4), we found that 


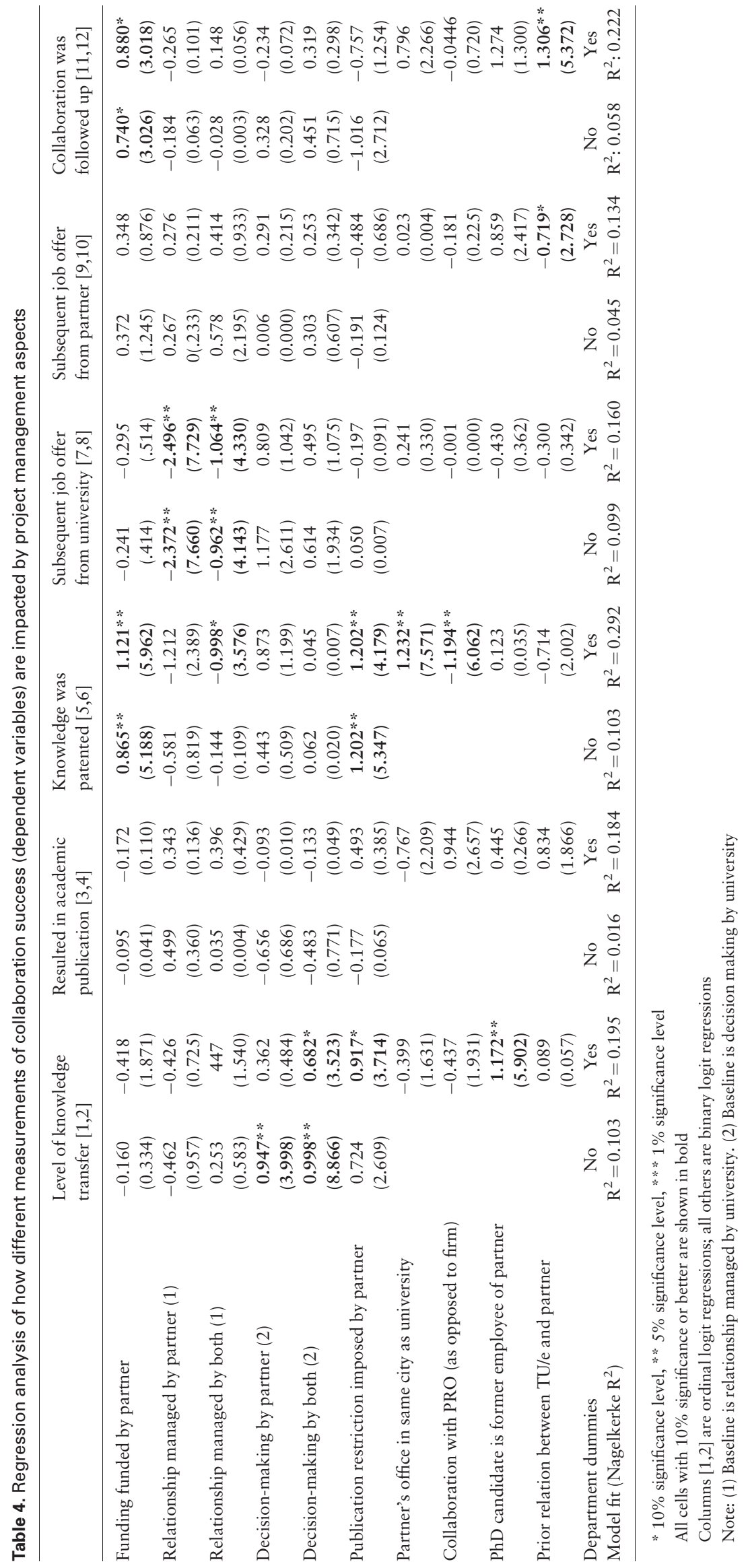




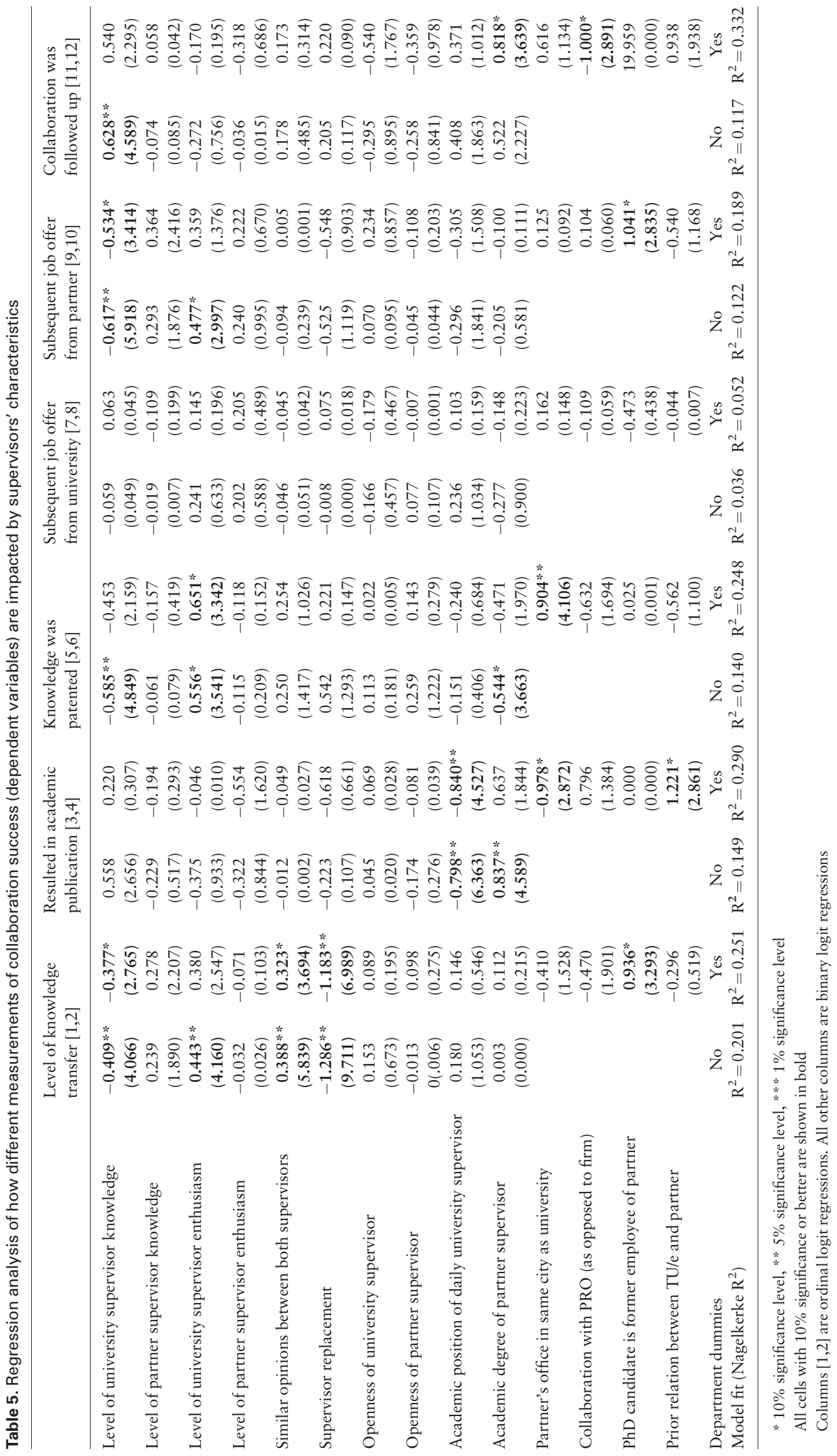




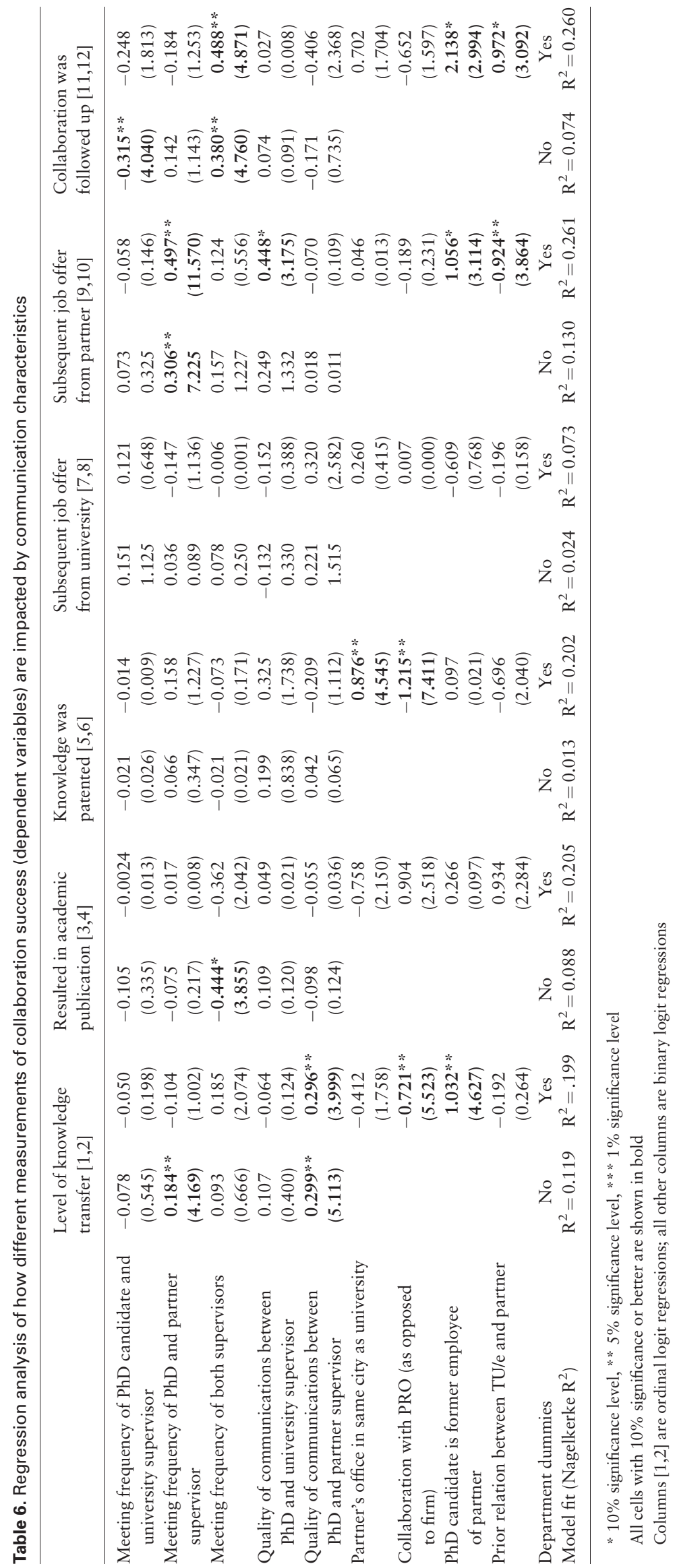


the likelihood of academic publications is negatively related to the university professor's academic position. University supervisors with a higher academic position are likely to have more managerial responsibilities as well as fewer incentives to publish compared to less senior colleagues. Consequently, the probability of publication might decrease. By adding control variables, the publication probability decreases if the partner's office is located in the same city as the university, which is unexpected. Prior relations between university and partners-indicative of trust between partners-increase the likelihood of academic publications.

Based on our third outcome variable, whether or not the $d e$ veloped knowledge is patented (Table 5, columns 5 and 6), we found that patenting is supported by a university supervisor's enthusiasm. In terms of control variables, co-location in Eindhoven increases the likelihood of patents. It should be noted that this effect is likely to be, at least partially, the result of collaborations with the Philips research in Eindhoven, which is very productive in terms of patenting.

For our fourth outcome variable, job offer to $\mathrm{PhD}$ from university (Table 5, columns 7 and 8), we found no significant relationships. None of the supervisor characteristics affects the likelihood of the PhD being offered a job by the university after successful completion of the project.

For the fifth outcome variable (Table 5, columns 9 and 10), we found that $a$ job offer by partner is less likely if the university supervisor is very knowledgeable. This may be because a knowledgeable university supervisor is likely to be more research-oriented and the partner focuses more on the commercialization aspects of knowledge. As expected, we also observe that it is more likely if the $\mathrm{PhD}$ candidate is a former employee of the partner.

Finally, for the sixth outcome variable, whether the collaboration was followed up by a new one (Table 5, columns 11 and 12), we found that such a follow-up is more likely if the partner supervisor's has a high academic degree, possibly cognitive proximity can facilitate new collaboration. Moreover, follow-up collaboration is less likely if the original collaboration is with a PRO than with a firm.

\subsection{How does communication affect collaboration success}

The regression results on how different measurements of collaboration success are influenced by communication are shown in Table 6.

Regarding the level of knowledge transfer (Table 6, columns 1 and 2), we found: first, it is positively related to the frequency of meetings between the $\mathrm{PhD}$ candidate and partner supervisor. As the $\mathrm{PhD}$ candidate has a role of knowledge transfer between university and industry (Thune 2009), the frequency of meetings between PhD candidates and their supervisor at the partner provides the conditions to facilitate transfer of knowledge through discussion, brain storming, etc. Second, the level of knowledge transfer is positively related to the quality of communication between the $\mathrm{PhD}$ candidate and collaborating partner. This result remains significant after adding control variables that show the robustness effect of this independent variable while the effect of frequency of meetings between $\mathrm{PhD}$ candidate and partner supervisor disappears. We also observed that a high level of knowledge transfer is less likely if the collaboration is with a PRO as opposed to a firm. Moreover, it is more likely if the $\mathrm{PhD}$ candidate is a former employee of the partner.

Regarding the second outcome, academic publications (Table 6, columns 3 and 4), we find no significant relationships. For our third and fourth outcome variables, patent and offering job to $\mathrm{PhD}$ from university (Table 6, columns 5-8), we find no significant relationships. We do observe that if the collaborating partner's office is in Eindhoven, a patent is more likely. Moreover, collaboration with a PRO compared to a firm reduces the likelihood of patents.

For our fifth outcome variable (Table 6, columns 9 and 10) we found that offering job to $\mathrm{PhD}$ from partner is: first, positively related to the high frequency of meetings between $\mathrm{PhD}$ and partner supervisor. Second, is positively related to the quality of communication between $\mathrm{PhD}$ candidate and university supervisor. After graduation, the $\mathrm{PhD}$ candidate is considered to be the main channel of knowledge transfer to the collaborating partner and tacit knowledge can be absorbed from this channel (Mangematin 2000). Moreover, close and frequent relationships play an important role in obtaining tacit knowledge (Tamer Cavusgil et al. 2003) and inspire the collaborating partner to hire a $\mathrm{PhD}$ candidate after graduation. Regarding the control variables, we again observed that the $\mathrm{PhD}$ candidate is more likely to receive a job offer from a partner if the candidate is a former employee and less likely to be offered a job if the university had already collaborated with the partner in question.

For the last outcome variable, following-up of collaboration by a new one (Table 6, columns 11 and 12), we found that a high frequency of meetings between both supervisors more often results into a follow-up collaboration. Arguably, this indicates that both sides find each other helpful in solving other problems, which could lead to new collaboration. By adding control variables, we observed that such a follow-up is more likely if the $\mathrm{PhD}$ candidate is a former employee of the partner and both partners have a prior mutual relationship. These results show the importance of social proximity in generating the trust and commitment, which in turn inspire them to continue collaboration.

\subsection{An integrated model}

The regression analyses we have presented so far on the effect of project management, supervision and communication on project performance, suffer from two limitations. First, each of the analyses assesses the effect of only one set of collaboration dimensions (project management, supervision, and communication). To assess the robustness of the results of the three separate regressions concerning these three dimensions, an additional analysis is required using a full model including all variables. Indeed, the results may change if the management, supervision and communication variables are interrelated in such a way that their joint inclusion would render some effects insignificant. Yet, given the number of observations $(N=191)$, we were compelled to reduce the number of independent variables for such a combined analysis. A second limitation is that some variables, both dependent and independent, are based on the subjective assessment of the $\mathrm{PhD}$ candidate in question. Hence, some findings may be based on unobservable individual characteristics (such as ability or personality) and could affect both their engagement in the $\mathrm{PhD}$ as measured by collaboration dimensions and the performance outcomes of the PhD project. We aimed to tackle both issues, albeit partially, by constructing an integrated model including project management, supervision and communication variables but excluding those variables most likely to suffer from individual candidate bias. We constructed an integrated model including all independent variables from the three separate analyses, but excluding the independent variables related to decision-making, levels of enthusiasm, similarity of opinions, openness and quality of communication. We also excluded the variable supervisor replacement because this is not 


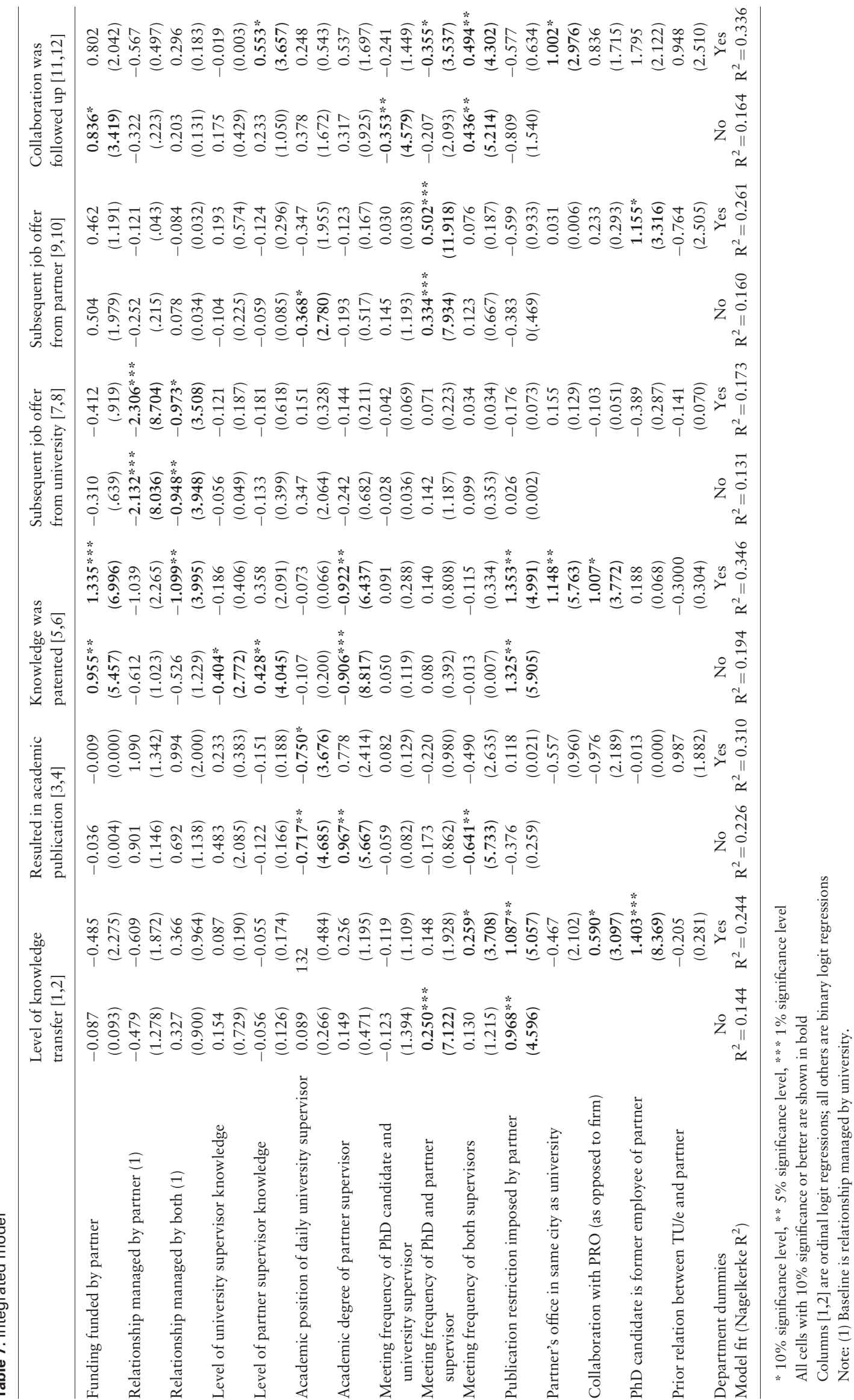


simply a dimension of collaboration but can also be regarded as a performance indicator. Entering the remaining independent variables in a single model may raise new multicollinearity issues between these variables. With VIF values in the range 1.055-1.638, however, we can safely conclude that the integrated model does not suffer from multicollinearity.

Table 7 presents the regression results of the integrated model. This model includes 11 independent variables plus control variables. By comparing the results of the three separate regressions (Tables 4-6), we found that the significant results in the three previous analyses, remain significant except for three variables. Concerning funding by partner, its positive effect on follow-up collaboration found in Table 4, is still positive but insignificant in Table 7 . With regard to the knowledge level of the university supervisor in Table 5, we no longer find any significant effect in Table 7. Finally, the positive effect of a high academic degree of the partner's supervisor on follow-up collaboration in Table 5, is no longer significant in Table 7.

Looking at the control variables in the integrated model, we recognize the effects observed before. Co-location in Eindhoven is associated with more patents indicative of a Philips effect. Interestingly, geographical proximity also favors follow-up collaboration suggesting that the Eindhoven region is supportive of long-term relationships. If we look at the difference between collaboration with a PROs versus a firm, we find that knowledge is more easily transferred to a PRO than to a firm, indicative of the benefits of institutional proximity. However, the negative effect of collaboration with a PRO on patenting in Tables 4 and 6, becomes positive in Table 7. That is, patenting is more likely if a PRO rather than a firm is the partner. A PhD candidate who previously worked as an employee for the partner, i.e. who is socially proximate to the partner, is better able to transfer knowledge and more likely to receive a job offer from the partner after the project. Finally, we find no effect of prior relationships between the university and the partner.

Hence, we conclude that, based on the full model, the main conclusions of the separate analyses remain intact.

\section{Discussion and conclusions}

This paper studied the factors that impact the success of collaborative $\mathrm{PhD}$ projects. We did so by three empirical analyses, focusing on potential explanatory success factors related to project management, characteristics of supervisors, and communications, respectively. To test the robustness of our results, we also tested one single model, including all possible success factors. We believe our study contributes to the existing literature, which rarely focused on collaborative PhD projects (Perkmann et al. 2013). The few studies done so far mostly compared the outcomes of collaborative $\mathrm{PhD}$ projects to non-collaborative projects rather than focusing on understanding success. We believe our study also has significant value for practitioners, as both universities and their collaborative partners may use our results to improve the likelihood of success of their joint projects. The latter is important because: first, there has been an increasing tendency to become involved in university-industry collaboration (Thursby and Kemp 2002); and second, collaboration is an inherently costly and risky activity for the partners (Thomson and Perry 2006), making it pivotal to maximize the probability of achieving substantial benefits from the collaboration. In fact, quite a few of the factors we found to impact success in a positive way, are factors that are within the control of the partners. In the reminder of this section, we discuss our main findings in relation to the existing literature, and discuss some limitations of our study.

\subsection{Decision-making}

Gemme and Gringas (2004) as well as Wallgren and Dahlgren (2005) suggested that students' experiences are influenced by different collaboration arrangements such as resource exchanges and features of the decision-making process. Our results show that, to promote collaboration success, implementing joint decision-making on the content of the project is appropriate. In fact, involving all partners in this decision-making process not only increases the synergy between them, but also provides a situation in which the collaboration partners contribute to determine their responsibilities and roles in collaboration. This allows partners in collaborations to follow and promote their beneficial expectations mutually (Artz and Brush 2000). Regarding the source of project funding, our findings suggest that the likelihood of success is increased when the partner organization funds the project (instead of the university).

\subsection{Supervisor's attitude, supervisor replacement}

Our study confirms the earlier findings of Butcher and Jeffrey (2007), among others, that the university supervisor's enthusiasm is a factors affecting the success of collaborative $\mathrm{PhD}$ projects. Our study now adds to this the (not so obvious) finding that this enthusiasm also increases patenting likelihood. This result that both university and their partner should select/look for truly committed academic staff when entering a collaborative project. Furthermore, supervisors in both university and its partner are a vital asset in collaboration (Thune 2009) and can provide an effective learning environment for the student. Therefore, replacing a supervisor is a challenging issue for every partner during a project, and is best avoided whenever possible. So, should a supervisor leave the university, it might be wise to try to agree that $s($ he) will nevertheless continue to supervise the collaborative $\mathrm{PhD}$ student. Furthermore, we advise the collaborating partner to oversee the frequency and quality of communication with the $\mathrm{PhD}$ candidate during the project. In fact, more frequent meetings facilitate the creation of mutual trust among partners and transferring knowledge (Bouba-Olga et al. 2012). Therefore, this finding emphasizes the importance of frequent face-to-face meetings between $\mathrm{PhD}$ candidates and supervisors.

\subsection{Publication restrictions}

Our findings concerning the effects of publication restrictions by partners may warrant additional discussion and perhaps call for future research. Publications restrictions are, as would be expected, positively related to patenting. But we also find that they render knowledge transfer more effective. Arguably, restrictions help in this respect, because companies might be more open to absorbing and adopting the outcome of the project if they have better chances to obtain exclusive rights in its use. Finally, we also find that publication restrictions do not negatively affect the likelihood of publication. This is an intriguing and perhaps puzzling outcome. It may be that there is some selection effect: studies with such restrictions may have been more promising in the first place, and have even had more publications if the same study was performed without that restriction. Another possible explanation is that there is a negative effect on the scope of publications-making them less valuable or lowering their impact from what it could have been had there been no 
restriction. Since we did not study the scope of publications, this might be a topic for further research.

\subsection{Previous collaboration experience}

Finally, having worked together on similar projects helps partners to achieve a higher level of success. We found that if the $\mathrm{PhD}$ candidate is a former employee of the university's partner, (s)he has more chance to be offered a job by the partner after graduation. This result confirms earlier findings (Mangematin 2000; Mougérou 2001), that the industry involvement in $\mathrm{PhD}$ projects leads to higher job opportunities. Having experience with collaboration, and partners' differences facing them, also facilitate the success of collaboration (Thune 2009). Hence, aiming at long-term partnerships rather than one-off projects is likely to pay off. Our study also adds to this finding that if both partners (university and its partner) have a prior mutual relationship, continuation of collaboration in terms of a new project increases.

\subsection{Limitations}

Our study has several limitations that could encourage researchers to continue work on collaborative $\mathrm{PhD}$ projects. One obvious limitation is that we only studied TU/e. As a technical university with close historical links to local industry, the results may to some extent be specific to this regional context of Eindhoven. We think more empirical studies are needed to examine the effect of collaboration dimensions on the success of collaborations in other technical universities, as well as other types of universities, to better validate the proposed model. Finding out how collaborative $\mathrm{PhD}$ projects are managed in other types of universities and conducting a comparative study among different universities, are just two interesting avenues for future research. Another limitation of this study is that it only considers $\mathrm{PhD}$ projects that have resulted in a published $\mathrm{PhD}$ thesis (i.e. a successful defense). While such projects achieve diverse scores with our collaboration success measurements, we have not included projects that, for whatever reason, were aborted during their execution. Although such data is much harder to collect, it might provide new insights into collaborative $\mathrm{PhD}$ projects. Moreover, it would be ideal to measure collaboration success from all the partners' perspectives (university, $\mathrm{PhD}$ candidate, and collaborating partner). However, gathering sufficient data for statistical analysis is problematic. Alternatively, case studies could be done to include the three perspectives in the analysis. Finally, it remains an open question as to whether the success factors we have determined for collaborative $\mathrm{PhD}$ projects also hold for non-collaborative projects. A final limitation is that this study specifically looked at university-industry collaborations in the form of $\mathrm{PhD}$ projects. Other forms of collaborations might be quite different, and more diverse in nature. They may last for very short or very long periods (whereas $\mathrm{PhD}$ collaborations are always approximately four years), they may have large research teams and high-level academic staff involved in carrying out the tasks (whereas in $\mathrm{PhD}$ collaborations the primary work is always carried out by a single $\mathrm{PhD}$ candidate). There may also be selection differences: in some cases (desire for fast answers, very high confidentiality, very uncertain types of research, etc.) companies may chose other forms of collaborations. Hence, our results are not necessarily generalizable to other forms of universityindustry collaborations.

\section{Acknowledgments}

Earlier versions of this paper were presented at a research seminar held at Eindhoven University of Technology's Department of Industrial Engineering and Innovation Sciences and at a colloquium at Delft University of Technology. We are very grateful for the comments and feedback provided by the participants. We also thank Delft University of Technology's Transport and Logistics group for their support and use of their facilities. Finally, we thank the useful comments of two anonymous reviewers.

\section{Notes}

1. We include all departments of the university, which include: Applied Physics, Chemical Engineering \& Chemistry, Electrical Engineering, Mathematics \& Computer Science, Mechanical Engineering, Built Environment, Biomedical Engineering, Industrial Design, and Industrial Engineering \& Innovation Sciences. In the analysis, we grouped the latter four into a single category 'Management or Design Department'.

2. In that sense, their behavior is not so different from firms in the context of our study (Bienkowska et al. 2010). However, we used a control variable to see whether our findings for PROs differ from those for firms (see Section 3.2).

3. A collaboration was derived from reading the preface of each $\mathrm{PhD}$ thesis, which-in the Dutch $\mathrm{PhD}$ system-typically acknowledges all collaboration partners.

4. Finding the supervisor(s) at a university and the contact person in industry is very difficult compared to tracking down a $\mathrm{PhD}$ candidate, even if that person graduated as long as 10 years ago. It is clear that in most cases, the $\mathrm{PhD}$ project is the only special project such a candidate has worked on during a threeto four-year period, whereas the same project may be only one of many with which a university or firm supervisor is involved. Finally, because it is the $\mathrm{PhD}$ candidate who actually conducted the research rather than the supervisors, the data obtained from a PhD candidate are likely to be more reliable than data obtained from supervisors (Behrens and Gray 2001). Other studies, such as that of Butcher and Jeffrey (2007), also evaluated collaborative projects in terms of being successful or unsuccessful from the PhD candidate's perspective due to considerations about response rate and quality of responses.

5. If the probability of obtaining a response from each actor $(\mathrm{PhD}$ candidate, university and collaborating partner supervisors) is independent, the overall response rate would be given by the product of individual response rates. For example, for a response rate of each actor of $40 \%$, the overall response rate would drop to $0.4 * 0.4 * 0.4=0.064$, which is obviously too low to obtain reliable results.

\section{References}

Amabile, T. M., Patterson, C., Mueller, J., Wojcik, T. et al. (2001) 'Academicpractitioner collaboration in management research: A case of cross-profession collaboration'. Academy of Management Journal, 44: 418-31.

Armstrong, J. S. and Overton, T. S. (1977) 'Estimating nonresponse bias in mail surveys'. Journal of Marketing Research, 14: 396-402.

Artz, K. W. and Brush, T. H. (2000) 'Asset specificity, uncertainty and relational norms: An examination of coordination costs in collaborative strategic alliances'. Journal of Economic Behavior and Organization, 41: 337-62.

Baldini, N. (2006) 'University patenting and licensing activity: A review of the literature'. Research Evaluation, 15: 197-207.

Balland, P. A. (2012) 'Proximity and the evolution of collaboration networks: Evidence from R\&D projects within the GNSS industry'. Regional Studies, 46: 741-56

Barnes, T., Pashby, I. and Gibbons, A. (2002) 'Effective university-industry interaction: A multi-case evaluation of collaborative R\&D projects'. European Management Journal, 20: 272-85. 
Beamish, P. W. and Inkpen, A. C. (1995) 'Keeping international joint ventures stable and profitable'. Long Range Planning, 28: 2-36.

Behrens, T. R. and Gray, D. O. (2001) 'Unintended consequences of cooperative research: Impact of industry sponsorship on climate for academic freedom and other graduate student outcome'. Research Policy, 30: 179-99.

Bekkers, R. and Bodas Freitas, I. M. (2008) 'Analysing knowledge transfer channels between universities and industry: To what degree do sectors also matter?' Research Policy, 37: 1837-53.

— and — (2011) 'The performance of university-industry collaborations: Empirical evidence from the Netherlands'. DRUID 2011 Summer Conference, held 15-7 June 2011, Copenhagen.

Bienkowska, D., Larsen, K. and Sörlin, S. (2010) 'Public-private innovation: Mediating roles and ICT niches of industrial research institutes'. Innovation: Management Policy and Practice, 12: 206-16.

Boschma, R. A. (2005) 'Proximity and innovation: A critical assessment'. Regional Studies, 39: 61-74.

Bouba-Olga, O., Ferru, M. and Pépin, D. (2012) 'Exploring spatial features of science-industry partnerships: A study on French data'. Papers in Regional Science, 91: 355-75.

Brouthers, K., Brouthers, L. and Harris, P. (1997) 'The five stages of the cooperative venture strategy process'. Journal of General Management, 23: $39-52$.

Butcher, J. and Jeffrey, P. (2007) 'A view from the coal face: UK research student perceptions of successful and unsuccessful collaborative projects'. Research Policy, 36: 1239-50.

Czarnitzki, D. and Fier, A. (2003) 'Publicly funded R\&D collaborations and patent outcome in Germany'. Discussion Paper No. 03-24. Mannheim, Germany: Centre for European Economic Research (ZEW).

D'Este, P. and Patel, P. (2007) 'University-industry linkages in the UK: What are the factors underlying the variety of interactions with industry?' Research Policy, 36: 1295-313.

Dodgson, M. (1991) 'The management of technological collaboration'. Engineering Management Journal, 1: 187-92.

Dutrénit, G., De Fuentes, C. and Torres, A. (2010) 'Channels of interaction between public research organisations and industry and their benefits: Evidence from Mexico'. Science and Public Policy, 37: 513-26.

Enders, J. (2002) 'Serving many masters: The PhD on the labour market, the everlasting need of inequality, and the premature death of Humboldt'. Higher Education, 44: 493-517.

Fernandes, A. C., De Souza, B. C., da Silva, A. S., Suzigan, W. et al. (2010) 'Academy-industry links in Brazil: Evidence about channels and benefits for firms and researchers'. Science and Public Policy, 37: 485-98.

Gemme, B. and Gringas, Y. (2004) 'Training a new breed of researchers, inside and outside universities'. Working paper presented at UNESCO Colloquium on Research and Higher Education Policy, held 1-3 December 2004, Paris.

Grimpe, C. and Hussinger, K. (2013) 'Formal and informal knowledge and technology transfer from academia to industry: Complementarity effects and innovation performance'. Industry and Innovation, 20: 683-700.

Hair, J. F., Black, W. C., Babin, B. J., Anderson, R. E. and Tatham, R. L. (2006) Multivariate Data Analysis: A Global Perspective. Upper Saddle River, NJ: Pearson Education.

Kelly, M. J., Schaan, J. L. and Joncas, H. (2002) 'Managing alliance relationships: Key challenges in the early stages of collaboration'. R\&D Management, 32: 11-22.

Lambert, D. M. (2008) Supply Chain Management: Process, Partnership, Performance, 3rd edn. Sarasota, FL: Supply Chain Management Institute.

Lin, M. W. and Bozeman, B. (2006) Researchers' industry experience and productivity in university-industry research centers: A "scientific and technical human capital" explanation'. Journal of Technology Transfer, 31: 269-90.

Mangematin, V. (2000) 'Ph.D. job market: Professional trajectories and incentives during the Ph.D. . Research Policy, 29: 741-56.

March, J. G. and Olsen, J. P. (1989) Rediscovering Institutions: The Organizational Basis of Politics. New York: Free Press.

Mattessich, P. W. and Monsey, B. R. (1992) 'Collaboration: What makes it work. A review of research literature on factors influencing successful collaboration'. St Paul, MN: Amherst H. Wilder Foundation.
Menard, S. (1995) Applied Logistic Regression Analysis (Quantitative Applications in the Social Sciences). Thousand Oaks, CA: Sage.

Morandi, V. (2013) 'The management of industry-university joint research projects: How do partners coordinate and control R\&D activities?' Journal of Technology Transfer, 38: 69-92.

Mougérou, P. (2001) 'Knowledge diffusion, bridging institutions and the scientific labour market in the French innovation system'. Paper presented at DRUID's Nelson and Winter Conference, held 12-5 June 2001, Aarlborg, Denmark <http://www.druid.dk/conferences/nw/paper1/moguerou.pdf $>$ accessed 19 Mar 2015.

Nelson, R. R. (2001) 'Observations on the post-Bayh-Dole rise of patenting at American universities'. Journal of Technology Transfer, 26: 13-9.

Ostrom, E. (1990) Governing the Commons: The Evolution of Institutions for Collective Action. Cambridge, UK: CUP.

Perkmann, M., Tartari, V., McKelvey, M., Autio, E. et al. (2013) 'Academic engagement and commercialisation: A review of the literature on university-industry relations'. Research Policy, 42: 423-42.

Podsakoff, P. M., Mackenzie, S. B., Lee, J. Y. and Podsakoff, N. P. (2003) 'Common method biases in behavioral research: A critical review of the literature and recommended remedies'. Journal of Applied Psychology, 88: 879-903.

Ponds, R., Van Oort, F. and Frenken, K. (2007) 'The geographical and institutional proximity of research collaboration'. Papers in Regional Science, 86: 423-43.

Rappert, B., Webster, A. and Charles, D. (1999) 'Making sense of diversity and reluctance: Academic-industrial relations and intellectual property'. Research Policy, 28: 873-90.

Ryan, J. G., Wafer, B. and Fitzgerald, M. (2008) 'University-industry collaboration: An issue for Ireland as an economy with high dependence on academic research'. Research Evaluation, 17: 294-302.

Salimi, N., Bekkers, R. and Frenken, K. (2015a) 'Governance mode choice in collaborative Ph.D. projects'. Journal of Technology Transfer, 40: 840-58.

— - — and — (2015b) 'Does working with industry come at a price? A study of doctoral candidates' performance in collaborative vs. non-collaborative Ph.D. projects'. Technovation, 41/2: 51-61.

Salminen-Karlsson, M. and Wallgren, L. (2008) 'The interaction of academic and industrial supervisors in graduate education: An investigation of industrial research schools'. Higher Education, 56: 77-93.

Santoro, M. D. (2000) 'Success breeds success: The linkage between relationship intensity and tangible outcomes in industry-university collaborative ventures'. Journal of High Technology Management Research, 11: 255-73.

Schartinger, D., Rammer, C., Fischer, M. M. and Fröhlich, J. (2002) 'Knowledge interactions between universities and industry in Austria: Sectoral patterns and determinants'. Research Policy, 31: 303-28.

Senker, J., Faulkner, W. and Velho, L. (1998) 'Science and technology knowledge flows between industrial and academic research: A comparative study' in Capitalizing Knowledge: New Intersections of Industry and Academia, H. Etzkowitz, A. Webster and P. Healey (eds), pp. 111-32. Albany, NY: State University of New York Press.

Shane, S. A. (2005) Economic Development Through Entrepreneurship: Government, University and Business. Cheltenham, UK: Edward Elgar.

Siegel, D. S., Waldman, D. A., Atwater, L. E. and Link, A. N. (2003a) Commercial knowledge transfers from universities to firms: Improving the effectiveness of university-industry collaboration'. Journal of High Technology Management Research, 14: 111-33.

— _ _ - and Link, A. (2003b) 'Assessing the impact of organizational practices on the relative productivity of university technology transfer offices: An exploratory study'. Research Policy, 32: 27-48.

Spekman, R. E., Forbes, T. M., Isabella, L. A. and MacAvoy, T. C. (1998) 'Alliance management: A view from the past and a look to the future'. Journal of Management Studies, 35: 747-72.

Starbuck, E. (2001) 'Optimizing university research collaborations'. Research Technology Management, 44: 40-4.

Stephan, P. E., Sumell, A. J., Black, G. C. and Adams, J. D. (2004) 'Doctoral education and economic development: The flow of new Ph.D.s to industry'. Economic Development Quarterly, 18: 151-67. 
Tamer Cavusgil, S., Calantone, R. J. and Zhao, Y. (2003) 'Tacit knowledge transfer and firm innovation capability'. Journal of Business and Industrial Marketing, 18: 6-21.

Thomson, A. M. and Perry, J. L. (2006) 'Collaboration processes: Inside the black box'. Public Administration Review, 66: 20-32.

Thune, T. (2009) 'Doctoral students on the university-industry interface: A review of the literature'. Higher Education, 58: 637-51.

Thursby, J. G., Jensen, R. and Thursby, M. C. (2001) 'Objectives, characteristics and outcomes of university licensing: A survey of major U.S. universities'. Journal of Technology Transfer, 26: 59-72.
— and Kemp, S. (2002) 'Growth and productive efficiency of university intellectual property licensing'. Research Policy, 31: 109-24.

Tijssen, R. J. (2012) 'Co-authored research publications and strategic analysis of public-private collaboration'. Research Evaluation, 21: 204-15.

Van Gils, M. J. G. M. (2012) 'The organization of industry-science collaboration in the Dutch chemical industry', PhD thesis, University of Nijmegen, the Netherlands.

Wallgren, L. and Dahlgren, L. O. (2005) 'Doctoral education as social practice for knowledge development. Conditions and demands encountered by industry PhD students'. Industry and Higher Education, 19: 433-43.

\section{Appendix}

Table A.1. Description of dependent variables

\begin{tabular}{|c|c|}
\hline Success measurements & Reference question in questionnaire \\
\hline $\begin{array}{l}\text { Level of knowledge transfer } \\
\text { to collaborating partner }\end{array}$ & $\begin{array}{l}\text { Please indicate the extent to which the knowledge you developed in your PhD thesis has been } \\
\text { taken up by the collaborating partner. Please select the highest appropriate item in this pro- } \\
\text { gressive scale. } \\
\text { - Not transferred at all } \\
\text { - Transferred the knowledge (is now effectively available to its staff working in this field, for } \\
\text { instance in the library, or has been presented to the staff) } \\
\text { - Absorbed the knowledge (i.e. its researchers have studied and now master this knowledge) } \\
\text { - Applied the knowledge in a business context } \\
\text { - Commercialized the knowledge as a (smaller) element of a product or process } \\
\text { - Commercialized the knowledge as the main basis or element or of a product or process }\end{array}$ \\
\hline Resulted in academic publication & $\begin{array}{l}\text { Did your PhD project result in scholarly publications in academic journals? } \\
\text { - No } \\
\text { - Yes }\end{array}$ \\
\hline Knowledge was patented & $\begin{array}{l}\text { Did your PhD project result in a patent or patent application with you as a listed inventor? } \\
\text { - No } \\
\text { - Yes }\end{array}$ \\
\hline Subsequent job offer from university & $\begin{array}{l}\text { After your PhD project was finalized, did the university offer you a position? } \\
\text { - No } \\
\text { - Yes }\end{array}$ \\
\hline Subsequent job offer from collaborating partner & $\begin{array}{l}\text { After your PhD project was finalized, did the collaborating partner offer you a position? } \\
\text { - No } \\
\text { - Yes }\end{array}$ \\
\hline Collaboration was followed up & $\begin{array}{l}\text { After your PhD project was finalized, did the university and the collaborating partner get engaged } \\
\text { in a new collaboration? } \\
\text { - No } \\
\text { - Yes }\end{array}$ \\
\hline
\end{tabular}


Table A.2. Description of independent variables

Governance Name of variable Reference question in the questionnaire

characteristics

Project management $\mathrm{PhD}$ project funder

Prominent partner in managing the coordination

Type of decision-making between both partners

Publication was prohibited due to the collaborating partner's restrictions

Supervision

Communication
Academic position of the university daily supervisor

Academic degree of the collaborating partner supervisor

Level of university supervisor's knowledge in $\mathrm{PhD}$ topic

Level of collaborating partner supervisor's knowledge in $\mathrm{PhD}$ topic

Level of university supervisor's enthusiasm in $\mathrm{PhD}$ topic

Level of collaborating partner supervisor's enthusiasm in $\mathrm{PhD}$ topic

Similar opinion between university and collaborating partner supervisors on $\mathrm{PhD}$ topic

Replacing any of the supervisors during the $\mathrm{PhD}$ project

Openness of university supervisor to any idea

Openness of collaborating partner supervisor to any idea

Meeting frequency of $\mathrm{PhD}$ candidate and university supervisor
Who funded your PhD project?

- The collaborating partner (either by direct employment or by a contract to the university)

- Others (e.g. the university own funds, a funding organization)

Which organization was most prominent in managing the coordination or relationship?

- The university

- The collaborating partner

- Both to the same degree

How was the decision-making in the project best characterized?

- Mostly done by university

- Mostly done by the collaborating partner

- Joint decision making with an equal involvement of both partners

Were there research results that could not be published because the collaborating partner wished to keep these confidential?

- No

- Yes

What was the position of your university daily supervisor when you started your $\mathrm{PhD}$ project?

- Assistant professor

- Associate professor

- professor

Scientific degree of your (main) supervisor at the collaborating partner when you started your project.

- Bachelor or Master

$-\mathrm{PhD}$

- Professor

How would you rate the knowledge of your university supervisor(s) in the specific topic of your $\mathrm{PhD}$ study? (Scale: very low to very high)

How would you rate the knowledge of your supervisor(s) at the collaborating partner in the specific topic of your Ph.D. study? (Scale: very low to very high)

How would you rate the enthusiasm/personal involvement of your university supervisor(s) in the specific topic of your PhD study? (Scale: very low to very high)

How would you rate the enthusiasm/personal involvement of your supervisor(s) at the collaborating partner in the specific topic of your PhD study? (Scale: very low to very high)

To what degree did the supervisor(s) at university and those at the collaborating partner usually agree (or have similar opinions) about choices concerning the project? (Scale: very low to very high)

Were any of your supervisors replaced during the course of your $\mathrm{PhD}$ project?

- No

- Yes

To what degree was your university supervisor(s) open to any idea or change in the project? (Scale: very low to very high)

To what degree was your supervisor(s) at the collaborating partner open to any idea or change in the project? (Scale: very low to very high)

Please indicate the average frequency of supervision meetings you had with (any of) your university supervisors. (Note: this is about supervision meetings, not about other events at which you met these persons)

- More than once a week

- About every week

- About every two weeks

- About every month

- About every 3 months

- About every 6 months

- Less than every 6 months 
Table A.2. Continued

\begin{tabular}{|c|c|c|}
\hline \multirow[t]{5}{*}{$\begin{array}{l}\text { Governance } \\
\text { characteristics }\end{array}$} & Name of variable & Reference question in the questionnaire \\
\hline & $\begin{array}{l}\text { Meeting frequency of } \mathrm{PhD} \text { candidate } \\
\text { and collaborating partner supervisor }\end{array}$ & $\begin{array}{l}\text { Please indicate the average frequency of supervision meetings you had with (any of) } \\
\text { the supervisors at the collaborating partner (Note: this is about supervision meet- } \\
\text { ings, not about other events at which you met these persons) } \\
\text { - More than once a week } \\
\text { - About every week } \\
\text { - About every two weeks } \\
\text { - About every month } \\
\text { - About every } 3 \text { months } \\
\text { - About every } 6 \text { months } \\
\text { - Less than every } 6 \text { months }\end{array}$ \\
\hline & Meeting frequency of both supervisors & $\begin{array}{l}\text { What was the frequency of meetings where both the supervisors of the university and } \\
\text { the supervisors at the collaborating partner were present? } \\
\text { - About every month } \\
\text { - About every } 3 \text { months } \\
\text { - About every } 6 \text { months } \\
\text { - About every year } \\
\text { - Less than every year }\end{array}$ \\
\hline & $\begin{array}{l}\text { Quality of communication between } \\
\text { PhD candidate and university } \\
\text { supervisor }\end{array}$ & $\begin{array}{l}\text { How would you rate the quality of communication between you and your university } \\
\text { supervisor(s)? (Scale: very low to very high) }\end{array}$ \\
\hline & $\begin{array}{l}\text { Quality of communication between } \\
\text { PhD candidate and collaborating } \\
\text { partner supervisor }\end{array}$ & $\begin{array}{l}\text { How would you rate the quality of communication between you and your super- } \\
\text { visor(s) at collaborating partner? (Scale: very low to very high) }\end{array}$ \\
\hline
\end{tabular}

Table A.3. Description of control variables

\begin{tabular}{|c|c|}
\hline Control variables & Reference question in questionnaire \\
\hline Partner's office in same city as university & $\begin{array}{l}\text { Indicate name of city and country of the offices of the collaborating } \\
\text { located: }\end{array}$ \\
\hline $\begin{array}{l}\text { Collaboration with research institute } \\
\text { (opposed to firm) }\end{array}$ & $\begin{array}{l}\text { Your PhD project was a collaboration between Eindhoven Universit } \\
\text { - A firm } \\
\text { - A research institute }\end{array}$ \\
\hline $\begin{array}{l}\text { PhD candidate is former employee of } \\
\text { partner }\end{array}$ & $\begin{array}{l}\text { Were you a former employee of the collaborating partner before you } \\
\text { - No } \\
\text { - Yes }\end{array}$ \\
\hline $\begin{array}{l}\text { Prior relationship between TU/e and col- } \\
\text { laborating partner }\end{array}$ & $\begin{array}{l}\text { Prior to your PhD project, have the supervisors from the university a } \\
\text { worked together (e.g. research, projects or collaborations)? } \\
\text { - No } \\
\text { - Yes } \\
\text { - Don't know }\end{array}$ \\
\hline $\begin{array}{l}\text { Differences between various disciplinary } \\
\text { departments at university }\end{array}$ & $\begin{array}{l}\text { In which university department did you conduct your PhD project? } \\
\text { - Applied Physics } \\
\text { - Biomedical Engineering } \\
\text { - Architectural Science } \\
\text { - Chemical Engineering } \\
\text { - Electrical Engineering } \\
\text { - Industrial Design } \\
\text { - Industrial Engineering \& Innovation Sciences } \\
\text { - Mathematics \& Computer Sciences } \\
\text { - Mechanical Engineering }\end{array}$ \\
\hline
\end{tabular}




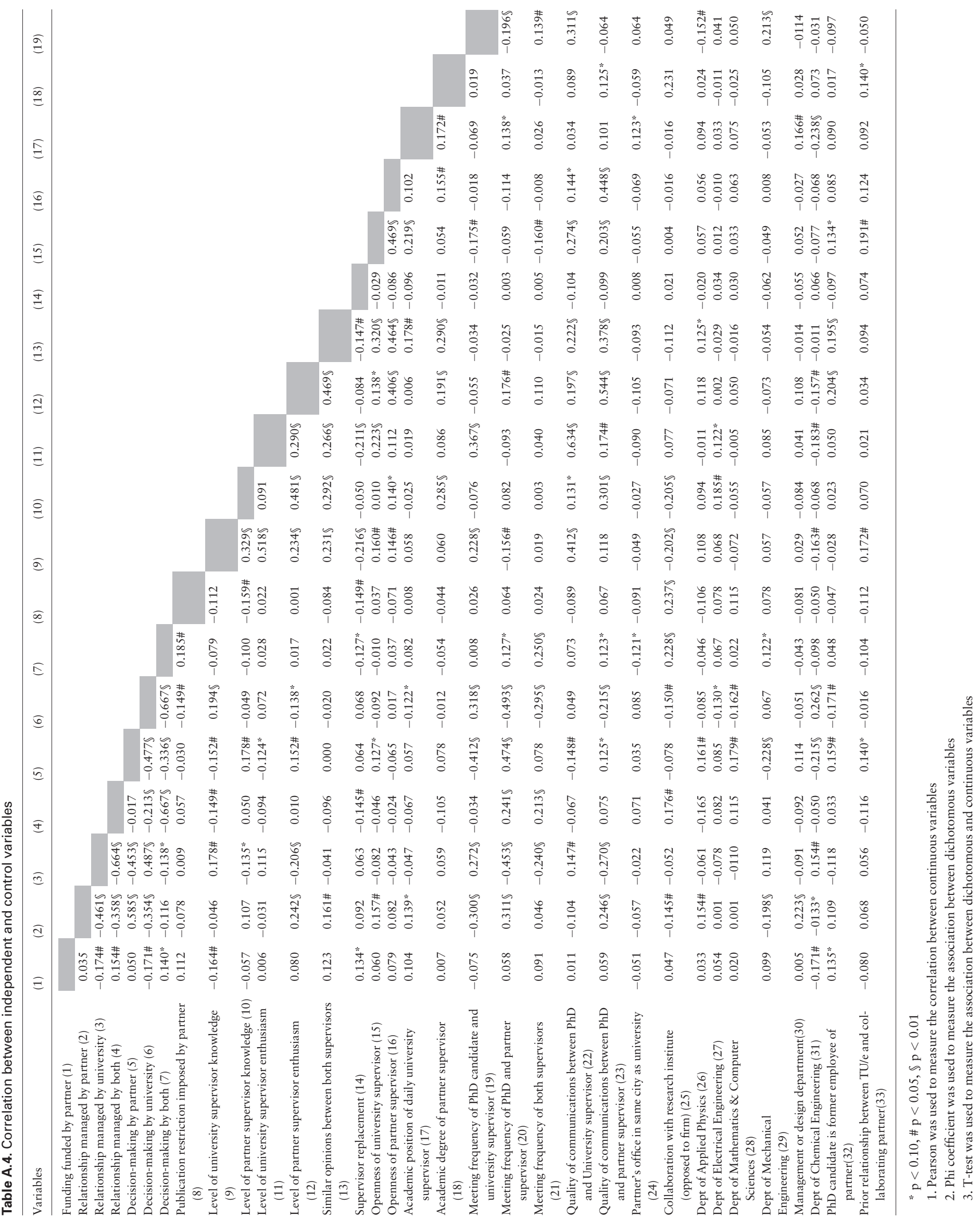




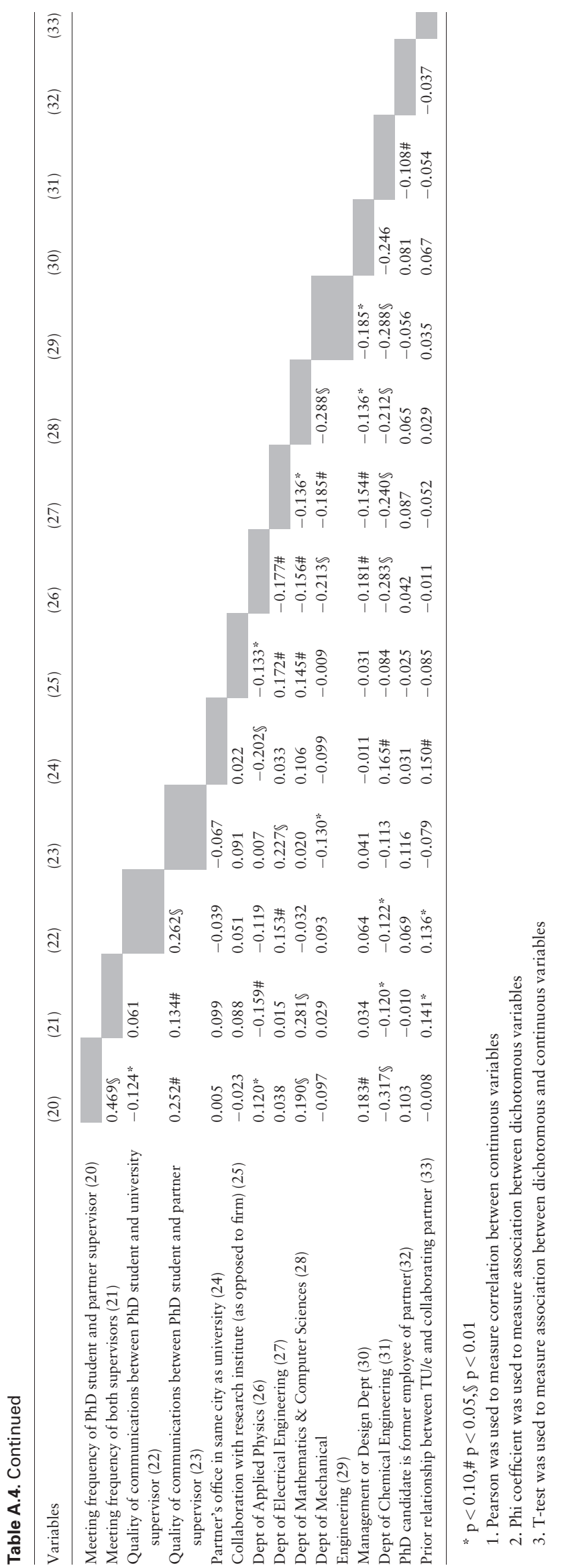

